\title{
Place Attachment in Urban Park Environments: The Case of King
}

\author{
Hussein Public Park in Amman, Jordan \\ Bsma Adel Bany Mohammad \\ Department of Architecture, College of Architecture and Design, Jordan University of Science \\ \& Technology P.O.Box 3030, Irbid 22110, Jordan
}

\begin{abstract}
In Jordan urban areas, the issue of less utilization of public parks continues instead of the apparently well-designed physical Environment.

Through analysis, the factors for park attachment defined and later assessed at King Hussein Public Park in Amman, a big city urban park serves the capital of Jordan, an observation between April and June followed by a questioner carried out from July to September over a group of 350 user chosen at random. The study concluded that the four factors (physical, emotional, social, and attraction) were very important to achieve the park success and should be used before the planning and design of such parks.

A correlation analysis showed the positive effect of the unique views, the variety of activity spaces, and the existence of a unique religious building, on the utilization and strong attachment to the park. The use was dominated by need for relaxing in green areas followed by personal health-related activities such as jogging, playing football, while social interaction was restricted within family members and close friends, which limits the park role as social integrators, the problem of insufficient continual maintenance and some unaccepted Social behaviors affect the park use and attachment.
\end{abstract}

Keywords: Urban Park; Place attachment, parks Design, Religious Building, Identity.

\section{Introduction}

Around the world, in many cases, well designed public parks have a lower utilization. One such case is found at the city of Amman, . Mohammad Qteish, director of GAM's (Greater Amman Municipality) public parks department, said there are around 140 public parks in the capital alone, with a plan to open 7 more by the end of 2017 "However, people still picnic on streets and in public areas," (Jordan Times, 2015). Despite its apparent good design, 
Peoples miss the place attachment.

The parks had an ecological and social benefit which is important in the development of the urban environment (Brown et al., 2003), they form a main part of the urban landscape which is closely linked to the community's shared identity (Inglis etal., 2008).

It is important to measure the urban environment meant to people and how they felt about it (Carmona et al., 2003). The place attachment concept provides a more holistic measure of place performance and place significance based on the users' experience of the place.

\section{The purpose of study}

To investigate the use of urban parks according to users experience and to define the factors of their successfulness. The goal of this study is to highlight that factors which motivate the user's utilization and consequently the park attachment.

This paper tray to highlights the factors of place attachment and their significance in the creation of a "sense of place". Sense of place is difficult to evaluate because of its ambiguity (Stedman, 2003). This is associated with the feelings and perceptions that people gain through their experience of a place (Relph, 1976). In people's experience of a place, physical structure, actions and cultural significance, combine to form a sense of place (Montgomery, 1998).

\section{Literature Review:}

\subsection{Public Parks and Place Attachment:}

Public park is a designed place natural and man-mad environment that surrounded by urban setting, they provide a varied space for recreation, meditation, tourist attractions, places to gather with family and friends, a place to enjoy the beauty of nature, and many others.

There are three broad, interrelated components that compose a place and give meaning to it: the physical setting, the individual's internal psychological and social processes, and activities that have been undertaken (Relph, 1976; Stedman, 2003). Successful parks allow the user to relax and get away from daily life through providing engaging elements such as vegetation and scenic views, there are different ways in which they can positively persuade happiness and health of users (Tzoulas et al. 2007).

Benefits can accrue from increased physical activity levels as a result of being in contact with nature (Bowler et al. 2010). Physical activity in turn unequivocally increases human health, both in physical, social and psychological terms (Ward, Parker, \& Shackleton, 2010; Noriah, Noralizawati, Mohd Hisham, \& Mohd Ali Waliyuddin, 2015). According to (Chiesura, 2004), urban park and urban green spaces are important for urbanized society in improving the quality of life. 
Most of urban park design takes into consideration the elements and equipment that are appropriate for outdoor activities, according to (Suria, Nik Hanita, \& Sabrina, 2013), urban parks mostly provided big scale outdoor exercise elements such as field, games court (badminton, tennis) and also swimming pool.

The affective bonds between users and places have recently raised concerns about place attachment studies (Gustafson, 2006; Raymond, Brown, \& Weber, 2010; Scannell \& Gifford, 2010;).

Place attachment is defined as "The affective link that people establish with place settings, where they tend to remain and where they feel comfortable and safe" (Hidalgo \& Hernandez, 2001), It is the positive bonding of people to a particular place (Manzo, 2005), Most psychologists believe that man's positive attachment to his/her environment is crucial for a healthy personality (Allport, 1955; Fromm, 1941 \& Maslow, 1967),the environment attachment is a cognitive bond between the user and the built environment. The environment had a strong image that connect the user emotionally and culturally (Altman \& Low, 1992). Lynch (1979) proposed that the main attribute of place identity is due the clear subjective image of it.

The Comfort and safety directly affect the attachment (Hidalgo et al. 2001), with the Climate as a significant factor that affects the social, economic, and cultural setting of a place, it also can have a direct association with the memories associated with that place (Knez, 2005).

In broader social, natural and physical environments such as an urban park, the user-environment connection may help the users by affecting their cognitions and behaviors (Lewicka, 2011a). Furthermore, for psychologists and sociologists, research on place attachment has a significant motivational potential for users to utilize public places further and spend more time outdoors to enhance social interaction (Manzo \& Perkins, 2006).

Successful parks can be seen by how it attracts users to come and get positive benefits from their facilities (Asmah \& Abdullah, 2014) that fulfill their needs.

\subsection{Determining the Place Attachment Aspects:}

The parks is an urban setting for (Smith et al.1997) the good quality design of urban settings should had : 1) livability (the basic qualities that must exist, such as survival, personal health and development, environmental health, comfort, and safety and security), 2) character (sense of place, warmth, sense of time, stability, and aesthetics), 3) connection (fit, continuity, unity, cultural symbolism, social interaction, and sense of belonging), 4) mobility (accessibility, convenience, opportunities for activity, and legibility), 5) personal freedom (degree of control, personal expression, privacy and territoriality, and affordability) and 6) diversity (variety, choice, interest, awareness). The Good quality of urban parks is directly related to the optional level of activities which enables owning of the place and becomes a 
factor in increasing the utilization frequency and social activities carried out in it (Gehl, 1987).

Rapoport (2004) determined that, in order to assure the good quality of place, we should consider the expectations of users and their sensory effects; Lennard (1987) suggests that the design of successful urban spaces should promote social life and a sense of wellbeing. Contemporary psychological defined 'well-being' as the attainment of happiness and pleasure, avoidance of pain and realization of human potential (Ryan and Deci, 2001).

The parks provide spaces for social interaction ,Lack of social interaction leads to a feeling of isolation resulted in lower levels of morale, and decreased the satisfaction with community life (Argent, 2008).

The qualified/eligible outdoor places according to Marcus and Francis (1990) is that which have easy access, interesting views; aesthetic attraction; activities that meet the users expectations; safe and natural environments; arranged according to climatic changes; and regularly maintained.

Kent and Madden (1998) of the Project for Public Spaces and the Urban Parks Institute, suggest that, "If urban parks can go from their recreational role, into a new one as a medium for community development and enhancement, parks will be an vital component in changing and developing our cities. Most important of all is sociability; the park should be a place to meet other people - an integral part of community life", another good predictor of a good park is the sense of recognition.

Familiarity is a generic feeling in which a situation, event, place, person or object directly provokes a subjective feeling of recognition which we then believe to be a memory (Nugent 2013). As a result, we recognize "it".

The physical features that bring a unique identity to a place also tend to increase place attachment (Shamsuddin \& Ujang, 2008). For example, the sacred structures can promote communal bonds. Religious ceremonies engage the believers to experience the places more. These places are treated as a collective property of the community and take up as an important part of the collective conscience, memory, identity, and history (Mazumdar, Sh., Mazumdar, 2004).

Based on the literature review, the Factors will be as shown in (Figure1) below, in addition, users' personal assessments and experience are also used to measure the quality of park. 


\section{Figure 1: Park Attachment Factors.}

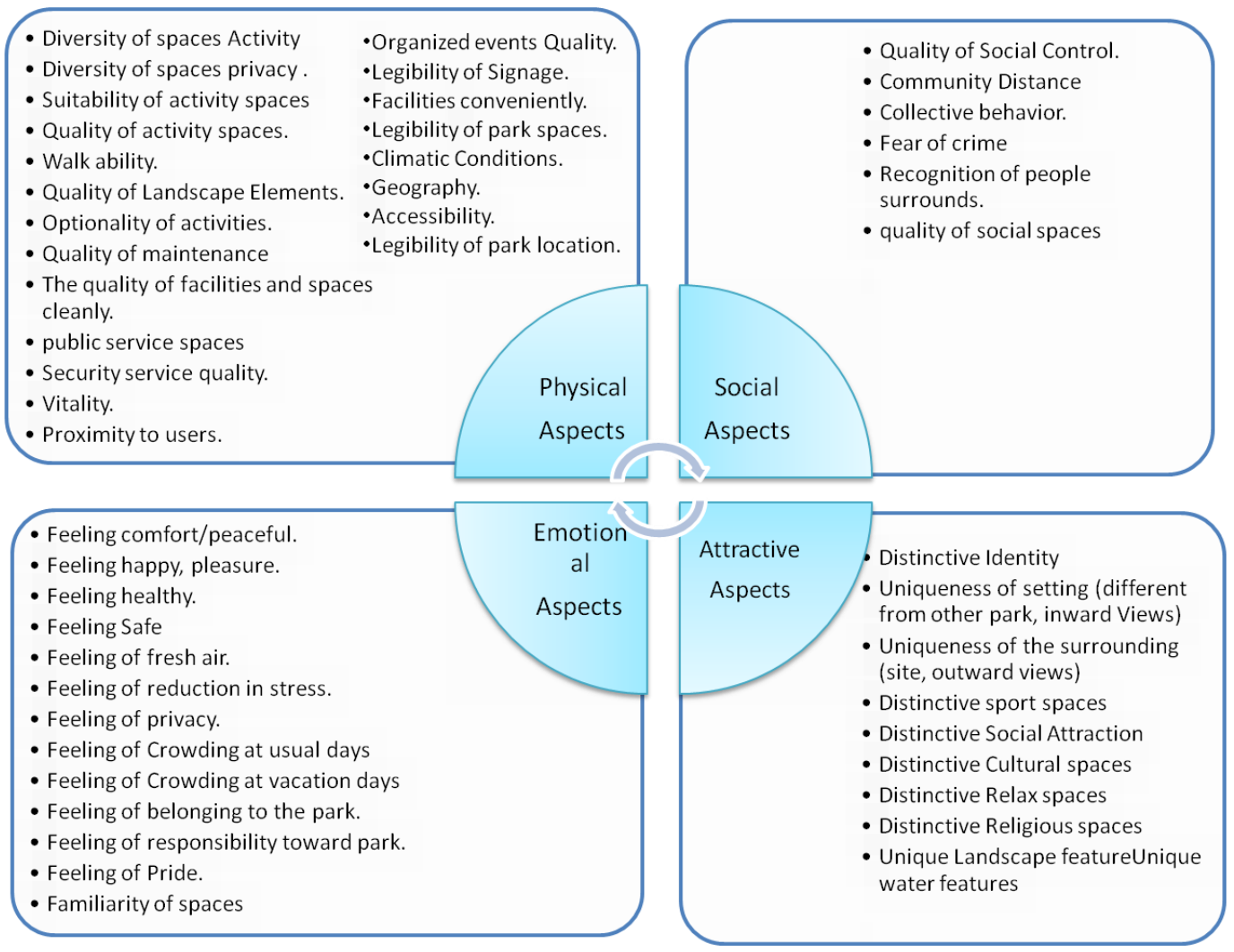

\section{Methods}

The research adopted qualitative investigation in determining the role of place attachment in park utilization by observation, partial-structured interviews, and a Quantitative questioner based on random sample.

The interviews were carried out during weekdays in the morning and evening. Respondents were asked about their park visits duration frequency, park facilities, greenery, familiarity, social interaction and of their experiences.

The Questioner based on the Park Attachment factors, given to a random sample size based on a confidence level $95 \%$ and Confidence interval 5 , according to an estimated population of 5000 Visitors per month (GAM ,2015) which is about 340. The evaluation related to the use of the study area was carried out from June to September, 2017. The questionnaire form consis of six parts prepared to determine the participants' opinions of King Hussein Public Park. The first section comprised demographic data (gender, age, profession); the second investigated the purpose and time of use and usage frequency of the places preferred in the park; from the third to the six part the questioner explore the quality of the users experience. The variables in the first part were independent, while the variables in the second part were dependent. 
SPSS (Version 18.0 for Windows) software was used for statistical analyses in this study; values were interpreted on the basis of frequencies and means. Frequencies were applied for the independent variables. Participants' opinions about the study area were determined by means of 5-point Likert type scale (very good, good, medium, bad, very bad) which was analyzed using mean values of the answers. The values were determined via the formula of Gap width=Range/group number, Gap width were determined as $=4 / 5=0.8$. The mean of the participant's answers was used as representing the park quality.

Table 1. Gap widths of Quintet Likert scale.

\begin{tabular}{|l|l|l|}
\hline Item & $\begin{array}{l}\text { Item } \\
\text { description }\end{array}$ & Score range \\
\hline 5 & Very good & $4.21-5.00$ \\
\hline 4 & Good & $3.41-4.20$ \\
\hline 3 & Moderate & $2.61-3.40$ \\
\hline 2 & Bad & $1.81-2.60$ \\
\hline 1 & very bad & $1.00-1.80$ \\
\hline
\end{tabular}

If the value is _ 3.40 the quality is bad; if the value is $>3.40$ the quality is good.

\section{The Study Area.}

Amman is the new administrative capital of Jordan. Planned in the early 1990's, In 1921, Abdullah I chose Amman instead of As-Salt as seat of government for his newly-created state, Amman remained a small city until 1949 , and by 1963 , the population expanded considerably due to an influx of Palestinian refugees from what is now Occupied Territories. Amman has experienced exceptionally rapid development since 2004. The city received refugees from different countries on a number of occasions, which resulted in a mixed community. During the last 10 years the number of new buildings within the city has increased dramatically with new districts of the city being founded at a very rapid pace (particularly so in West Amman), straining the very scarce water supplies of Jordan as a whole.

Amman's location and altitude has a big effect on its climate, its position on the mountains near the Mediterranean climate zone places it under the semi-arid climate, Summers in Amman (May to September) are hot and dry with cool evenings, whereas the coldest weather is in December and January.(GAM 2016)

\subsection{King Hussein Public Park (KP)}


A large hillside on the western outskirts of the city around (3323.5ft) above sea level. king Hussein Public Parks(KP) is one of the landmarks in Amman. It is classified as Urban Park which had large area about 70 acers, act on a city wide provide an escape for multiple communities, situated along an arterial street with a major transit route .

The Parks include a cultural village, sports fields, memorial building, historical passageway, decorated gardens, amphitheater for 150 person, traffic park, walls and gates, decorated gardens, circular yard, King Hussein Mosque, The Children's Museum, The Cultural Village and The Royal Automobile Museum.

The park houses a mural wall painting constructed on a (1601 ft) displays Jordan's history from the beginning to present times, with main historical events mark each section. The sports area has Facilities for football, basketball, volleyball, and tennis, with a camping area and stone bleachers that can hold 150 spectators. The park is among the best place to enjoy a panoramic view of Amman.

\section{Results and Discussion:}

The findings show a significant attachment to the park. Based on preliminary observation, the usage of the parks intensified particularly during weekends, the usage intensity according to seasons, mainly intensive in the months from April to October. The results indicate the role of sport facilities and religious building in the park attachment. The social interaction was limited and centered in specific groups of friends and relatives, the low level of maintenance, and the uncivilized behavior by particular youth groups play a central role in the less attachment to the park.

The survey consisted of 350 questionnaires completed by randomly chosen visitors of the site (51.3\% female, $48.7 \%$ male). It was determined that King Hussein Park was mostly used by the 20 s age group (27.3\%) followed by 30 s $(24.7 \%)$ then 40 s $(20.7 \%)$ and $(14.7 \%)$ below 20 and finally (12.7\%) above 50 . It was found that $33.3 \%$ of the users of the park are university students in addition to $14 \%$ postgraduates, $28.7 \%$ are high school graduates and $20.0 \%$ who is a composite of non-educated or the ones who had professional studies, while. In terms of usage, it was found that $60.7 \%$ of respondents used the park at weekends, compared with $39.3 \%$ of who used the park on weekdays.

While $62.7 \%$ use once weekly, $6.7 \%$ visited it rarely ( 1 or less monthly). The participants mostly (68.8\%) used the area between the hours of 15.00 and 21.00 . This high proportion is influenced by the park's location in the city edge and the presence of public institutions, and surrounding large shopping malls . the park used intensively from May to September especially at July and August, while less used in March and April, rarely from October to February, this is directly related to the city's Mediterranean climate that is hot during spring and summer months, The quality of the cooled fresh air in the park high areas attract most 
visitors at weekend nights, during sunny and hot months of July and august. Most of the survey participants stated that they used private cars 60.4 or public transportation $20.1 \%$ to visit the area. The less residences nearby are a factor decreasing the proportion of people coming to the park on foot to $10.5 \%$.

King Hussein Mosque which situated in the west park area attracts large numbers of domestic and foreign users during all season of the year. Therefore, it was observed that the northwest green areas of the park near the mosque is the most intensively used part of the park (61.9\%) In addition, it was also found that King Hussein Mosque and its premises were intensively used by people living in the city for the purpose of worship, especially at mid-day on Fridays, and in the holy month of Ramadan.

The questionnaire results show that $33.3 \%$ of participants preferred to use green areas, this usage category is followed by walking and using the sport areas (25.3\%) followed by the use of Entertainment areas (20.7\%).The percentage of people using the Cultural Areas 11.3 while Social spaces take the least with (9.3\%).

The sport facilities, take the second highest area for use basically the football courts and the jogging track used for playing in specific friend groups, or alone, training and entertaining for specific hours.

For the cultural activities It was found that the enclosed areas such as the Children museum and Automobile museum were preferred mostly all around the year, and more in cold weather of December and June, activated mostly by special organizations (such as tourist or educational) (85.4\%). the cultural activities in cultural village takes the least attraction and use (14.6\%).

Table 2. Assessment of Study area in terms of its Physical Design Aspects

\begin{tabular}{|l|c|c|}
\hline Physical Design Aspects & Mean & Std. Deviation \\
\hline Diversity of spaces Activity & 4.0867 & .69453 \\
\hline Diversity of spaces privacy & 2.9267 & .89064 \\
\hline Suitability of activity spaces & 3.9067 & .78018 \\
\hline Quality of activity spaces. & 3.9667 & .72738 \\
\hline Walkability. & 3.9600 & .93321 \\
\hline Quality of Landscape Elements & 4.1333 & .83277 \\
\hline Optionality of activities. & 3.3200 & .93636 \\
\hline Quality of maintenance & 1.8933 & 4.90192 \\
\hline The quality of facilities and spaces cleanly. & 1.9800 & .93799 \\
\hline public service spaces & 2.0800 & .69049 \\
\hline Security service quality. & 2.2933 & .93799 \\
\hline
\end{tabular}




\begin{tabular}{|l|c|c|}
\hline Organized events Quality. & 3.3267 & .93763 \\
\hline Legibility of Signage & 3.3733 & .68097 \\
\hline facilities Number conveniently & 2.6467 & .87575 \\
\hline Legibility of park spaces. & 3.4733 & .79171 \\
\hline Climatic. & 4.21 & .726 \\
\hline Geography. & 3.68 & 1.083 \\
\hline Accessibility. & 3.20 & 1.105 \\
\hline Legibility of park location & 4.49 & .653 \\
\hline Vitality. & 4.47 & .652 \\
\hline Proximity to users. & 2.06 & 1.044 \\
\hline General Mean & 3.3084 & \\
\hline
\end{tabular}

$\mathrm{X}=$ Mean, $\mathrm{S}=\mathrm{Std}$. Deviation

The result shows the goodness of activity spaces in terms of Quality, diversity and suitability, with the goodness geography, landscape, Legibility of park location, and walkability while maintenance, Security, clean, Public services, privacy and Proximity to users were found as "bad". Easy access and high legibility are effective aspects in defining a highly-qualified park, the Accessibility was average (3.2), while the legibility was very good (4.49), Diversity of activities mean $(X=4.08=$ good $)$, the users define the climate and location as very good, with the vitality of park. Based on the mean category responses, the general assessment of the park is "Average", with a value of $X=3.30$ (Table 2).

Examining the mean questionnaire responses, it was concluded that the accessibility of the study area was "Average", with a value of $X=3.2$. Users coming to the park on foot and by bicycle stated that they could not reach the park easily and comfortably, users visiting the park with private cars stated that they did not prefer to come to the park as there was lack of parking lots in and around the park.

Overall, $71.3 \%$ of respondents felt that the sitting areas had a good Design for socialization, since they were arranged and designed for group use. 
Table 3. Assessment of Study area in terms of Social Aspects

\begin{tabular}{|l|c|c|}
\hline Social Aspect & $\mathrm{X}$ & $\mathrm{S}$ \\
\hline Quality of Social Control. & 1.8533 & 1.06429 \\
\hline Community Distance & 1.7933 & .98510 \\
\hline Collective behavior. & 3.1333 & 1.09094 \\
\hline Fear of crime & 2.3400 & .65364 \\
\hline Recognition of people surrounds. & 1.7333 & .70155 \\
\hline Quality of social spaces & 4.661 & .91532 \\
\hline General & 2.585 & \\
\hline
\end{tabular}

$\mathrm{X}=$ Mean, $\mathrm{S}=\mathrm{Std}$. Deviation

Factors such as a good first impression of the park $(x=3.61)$ was good as the use of appropriate materials (3.77), and activity areas' complying with the standards the presence of sufficient and ergonomic seating $(x=4.01)$, while the complain of park management appeared by users $(x=2.032)$ which affect the quality of the park (PPS, 2001).for the park emotional impact on the participant and based on the mean category it is "Very Good" with a value of $(X=4.004)$ (Table 4$)$.

Table 4 . Assessment of Study area in terms of its Emotional Aspects.

\begin{tabular}{|l|c|c|}
\hline Emotional Aspect & $\mathrm{X}$ & $\mathrm{S}$ \\
\hline Feeling comfort/peaceful. & 4.3333 & .71884 \\
\hline Feeling happy, pleasure. & 4.4067 & .76058 \\
\hline Feeling healthy. & 4.5267 & .63136 \\
\hline Feeling Safe & 3.6200 & .62035 \\
\hline Feeling of fresh air. & 4.6400 & .58252 \\
\hline Feeling of reduction in stress. & 4.0333 & 1.14936 \\
\hline Feeling of privacy. & 2.8200 & .95587 \\
\hline Feeling of Crowding at usual days & 4.5867 & .77846 \\
\hline Feeling of Crowding at vacation days & 2.8933 & .61510 \\
\hline Feeling of belonging to the park. & 4.4133 & .60409 \\
\hline Feeling of responsibility toward park. & 3.3200 & .89981 \\
\hline Feeling of Pride. & 4.5733 & .58329 \\
\hline Familiarity of spaces & 3.8867 & .62965 \\
\hline General Mean & 4.004 & .7330 \\
\hline
\end{tabular}

$\mathrm{X}=$ Mean, $\mathrm{S}=\mathrm{Std}$. Deviation 
Finally, the attractive aspects which identify the unique identity and meaning attributed to the park had A "good "quality with a general mean of (3.8), Table 5 below summarize the Aspects mean results.

Table 5. Assessment of Study area in terms of its Attractive Aspects.

\begin{tabular}{|l|c|c|}
\hline Attractive Aspects. & $\mathrm{X}$ & $\mathrm{S}$ \\
\hline Distinctive Identity & 4.1533 & .64232 \\
\hline Uniqueness of setting (different from other park, inward Views) & 4.5000 & .55260 \\
\hline Uniqueness of the surrounding (site, outward views) & 4.587 & .5457 \\
\hline Distinctive sport spaces & 4.1867 & .73628 \\
\hline Distinctive Social Attraction & 3.2000 & .73274 \\
\hline Distinctive Cultural spaces & 3.2000 & .73274 \\
\hline Distinctive Relax spaces & 3.2000 & .73274 \\
\hline Distinctive Religious spaces & 4.2000 & .63457 \\
\hline Unique Landscape features & 4.233 & .8062 \\
\hline Unique water features & 2.8267 & .77500 \\
\hline General Mean & 3.828 & 0.689 \\
\hline
\end{tabular}

$\mathrm{X}=$ Mean, $\mathrm{S}=\mathrm{Std}$. Deviation

A Pearson product-moment correlation coefficient was computed to assess the relationship between Duration and frequency of park use and the place attachment Factors, there was a positive correlation between the duration (and frequent) of park use and the attractive aspects $r=.207, n=350, p=0.11$. a complete list of correlation is presented in (Table 6) . Overall, the increase of use was correlated with increases in the appreciation by the users for the attractive aspects of park spaces.

Table 6 : correlation for use $(\mathrm{N}=350)$

\begin{tabular}{|l|l|l|l|l|l|}
\hline \multicolumn{2}{|c|}{} & physical & Social & Emotional & Attractive \\
\hline \multirow{4}{*}{$\begin{array}{l}\text { Use } \\
\text { Duration }\end{array}$} & $\begin{array}{l}\text { Pearson } \\
\text { Correlation }\end{array}$ & .006 & .073 & -.034 & $.207^{*}$ \\
\cline { 2 - 6 } & $\begin{array}{l}\text { Sig. } \\
(2 \text {-tailed })\end{array}$ & .947 & .374 & .676 & .011 \\
\cline { 2 - 6 } & $\mathrm{N}$ & 350 & 350 & 350 & 350 \\
\hline \multicolumn{7}{|l|}{ Note: * Correlation is significant at the 0.05 level (2-tailed). } \\
\hline
\end{tabular}

Another detailed Pearson product-moment correlation coefficient was computed to assess the relationship between Duration and frequency of park use and the attractive Aspects 
individually, there was a positive correlation between the duration and frequency of park use and the Distinctive Identity, $r=.482, n=350, p=0.00$, also There found a positive correlation between the park use duration and the appreciation for the Distinctive Religious spaces, $r=.323, n=350, p=0.00$. a complete list of correlation is presented in( Table 7 )below, Overall, there was a strong, positive correlation between the users attachment to the park and the feeling of strong identity, with the existing of religious building, the increase of use was correlated with increases in identity feeling of space, and the religious use of the mosque in the park, which is shown in detailed in Figure 2 and Figure 3 below.

Table 7 : Correlation for use $(\mathrm{N}=350)$

\begin{tabular}{|c|c|c|c|c|c|c|c|c|c|c|}
\hline & 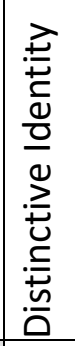 & $\begin{array}{l}\widetilde{y} \\
\frac{\tilde{U}}{d} \\
\frac{\partial}{\partial} \\
\frac{\partial}{\partial}\end{array}$ & 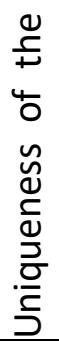 & 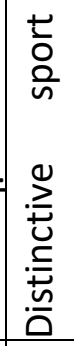 & 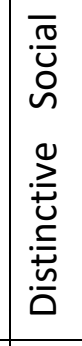 & 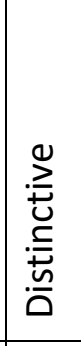 & 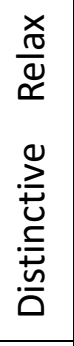 & 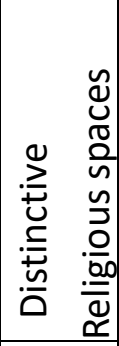 & 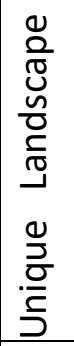 & $\begin{array}{l}\frac{1}{ \pm} \\
\frac{1}{\pi} \\
3 \\
\\
\frac{0}{2} \\
. \frac{0}{2} \\
\frac{0}{D} \\
\end{array}$ \\
\hline Use & & & & & & & & & & \\
\hline Duration & & 02 & בU. & כJ. & 08 & 08 & .08 & $323^{* *}$ & .06 & $\mid .072$ \\
\hline \multicolumn{11}{|l|}{ **. Col } \\
\hline
\end{tabular}

Figure 2. The correlation plot for the cultural identity resulted from setting and the use Duration and frequency.

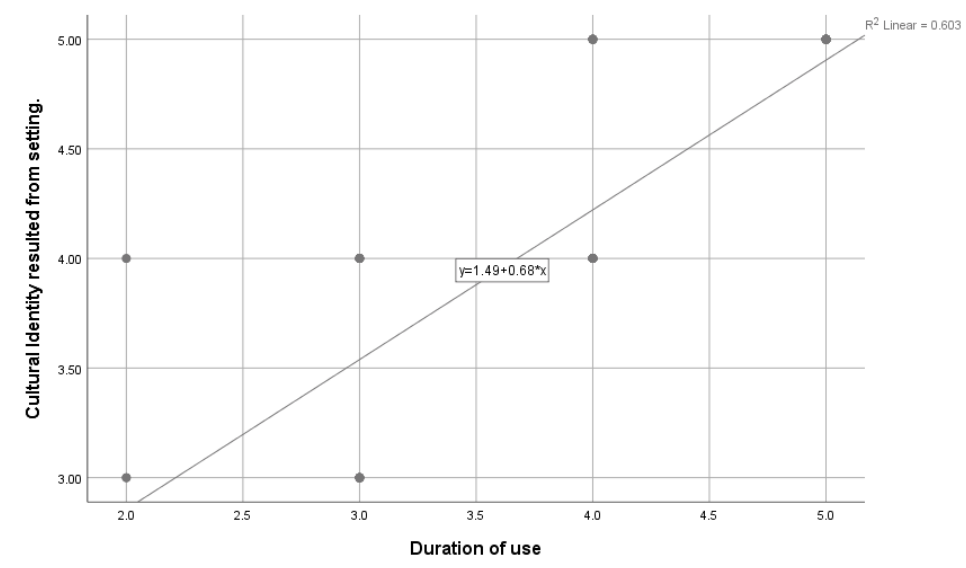

Figure 3. The correlation plot for the Distinctive Religious spaces and the use Duration and frequency. 


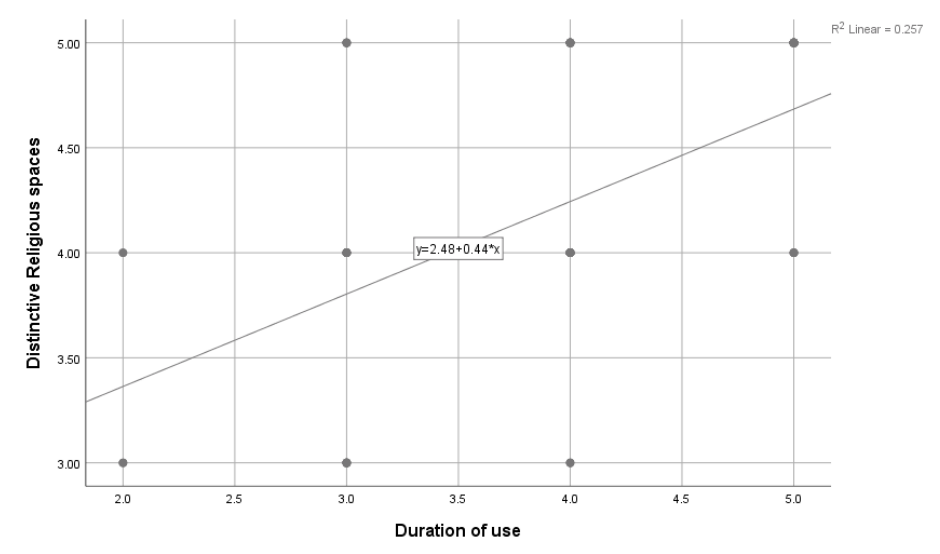

\section{Conclusions}

- The research asserts the role of place attachment factors in making parks more usable, resulting in stronger public park utilization.

Analysis of the fieldwork, including observations, and verbal interviews, produced the following conclusions:

- Urban parks provide natural environments that help overcome urban stress and thus play an important role in increasing the quality of urban life. Assessment of the success of such places depends on sensorial, emotional and mental relationships between the users and the environment.

- If There is easy access to the park by means of public transportation vehicles and private vehicles; there is clear signage and activities are easy for visitors to locate. This permits users to navigate the park and easily find various locations, thereby positively affecting visitor perceptions of legibility and safety that increase park utilization.

- The sense of identity and emotional meaning of the park could contribute to enhanced park utilization. If the park spaces designed to form a center for user cultural and pride issues.

- For sensorial design, the parks - which have a good character/ image play an important role in users assessment of the park as unique from others and have a feeling of attachment, spatially when the park had a Religious Features that define a strong spirit and sincerity, which create an identity.

- In the design of urban parks, it is expected that they should provide the opportunity for optional and social activities such as popular activities, recreation, entertainment, the opportunity for socializing increase the user's social commitment.

- The importance of the park as a social space is partially fulfilled if the functional (physical) attachment to the park is strong. The park spaces in the city have a great potential to develop a social support that is meaning to the life of community members.

- The maintenance and management quality of urban parks is very strong indicator of 
Park attachment, the utilization is strongly related to the regular maintenance and repairs, this give the users a feel of comfortable and safe.

\section{References}

- Brown, B., Perkin, D., \& Brown, G. (2003). Place attachment in a revitalizing neighbourhood: Individual and block levels of analysis. Journal of Environmental Psychology, 23, 259-271.

- Inglis, J, Deery, M and Whitelaw, P. (2008). The Development of Place Attachment in Parks Sustainable Tourism, Crc Tech Report Feedback National Library of Australia Cataloguing-In-Publication Entry. Sustainable Tourism Cooperative Research Centre, Queensland.

- $\quad$ Carmona, M, Tiesdell, S, Heath, T, and Oc, T., (2003). Public Spaces-Urban Spaces: The Dimensions of Urban Design. Architecture Press.

- $\quad$ Relph, E. (1976). Place and placelessness. London: Pion.

- Montgomery, J. (1998). Making a city: Urbanity, vitality and urban design. Journal of Urban Design, 3, 93-116.

- Tzoulas, K., Korpela, K., Venn, S., Yli-Pelkonen, V., Kázmierczak, A., Niemela, J., James, P., 2007.

- Bowler, D.E., Lisette, M.B.A., Knight, T.M., Pullin, A.S., 2010. A systematic review of evidence for the added benefits to health of exposure to natural environments. BMC Public Health 10, 456.

- Noriah, O., Noralizawati, M., Mohd Hisham, A., \& Mohd Ali Waliyuddin, A. R. (2015). Landscape visual studies in urban setting and its relationship in motivational theory. Procedia - Social and Behavioral Sciences.

- Ward, C. D., Parker, C. M., \& Shackleton, C. M. (2010). The use and appreciation of botanical gardens as urban green spaces in South Africa. Urban Forestry and Urban Greening, 9, 49-55.

- Chiesura, A. (2004). The role of urban parks for the sustainable city. Landscape and Urban Planning, 68, 129-138.

- Suria, S., Nik Hanita, N. M., \& Sabrina, I. (2013). Contribution of vegetation in urban parks as habitat for selective bird community. Procedia - Social and Behavioral Sciences, 85, 267-281.

- Manzo, L. C. (2005). For better or worse: Exploring multiple dimensions of place meaning. Journal of Environmental Psychology, 25, 67-86.

- Lewicka, M. (2011a). Place attachment: How far have we come in the last 40 years? Journal of Environmental Psychology, 31, 207-230. 
- Manzo, L. C., \& Perkins, D. D. (2006). Neighborhoods as common ground: The importance of place attachment to community participation and development. Journal of Planning Literature, 20, 335-350.

- $\quad$ Asmah, Y., \& Abdullah, M. (2013). Products attributes as attraction and as pull factors towards sustaining visitation to Putrajaya Botanical

- $\quad$ Garden. Pertanika Journal of Social Sciences \& Humanities, 21, 979-994.

- Gustafson, P. (2006). Place attachment and mobility. In N. McIntyre, \& et al (Eds.). Multiple dwelling and Tozirism: Negotiating place, home and identity. Cambridge: CABI.

- $\quad$ Raymond, C. M., Brown, G., \& Weber, D. (2010). The measurement of place attachment: Personal, community, and environmental connections. Journal of Environmental Psychology, 30, 422-434.

- Scannell, L., \& Gifford, R. (2010). Defining place attachment: A tripartite organizing framework. Journal of Environmental Psychology, 30, 1-10.

- $\quad$ Smith T, Nelischer M, Perkins N (1997). Quality of an Urban Community: a Framework for Understanding the Relationship Between Quality and Physical Form. Landsc. Urban Plann., 39: 229-241.

- Gehl J (1987). Life Between Buildings, New York: Van Nostrand Reinhold.

- $\quad$ Altman, I. \& Low, S. M. (1992). Place Attachment. New York: Plenum Press.

- Hidalgo, M. C. \& Hernandez, B. (2001). Place Attachment: Conceptual and empirical questions, Journal of Environmental Psychology, 21, 273-281.

- Knez, I. (2005). Attachment and identity as related to a place and its perceived climate. Journal of Environmental Psychology, 25, 207-218.

- $\quad$ Allport, G. (1955). Becoming: Basic Considerations for a Psychology of Personality. New Haven: Yale University Press.

- Stedman, R. C. (2003). Is it really just a social construction? The contribution of the physical environment to sense of place. Society\& Natural Resources, 16, 671-685.

- Lennard SHC (1987). Livable Cities. People and Places: social design principles for the future of the city. Gondolier Press, Southampton, NY.

- $\quad$ Ryan, R.M., and Deci, E. L. (2001).On Happiness And Human Potentials: A Review of Research on Hedonic and Eudaimonic Well-Being.Annual

- $\quad$ Argent, Neil. (2008). Perceived Density, Social Interaction and Morale In New South Wales Rural Communities. Journal of Rural Studies. 24, 245-261.

- Maslow, A. H. (1967). Self-Actualization and Beyond. In J. F. T. Bugental, ed., Challenges of Humanistic Psychology. New York: McGraw-Hill, pp. 279-86.

- $\quad$ Altman, I. \& Low, S. M. (1992). Place Attachment. New York: Plenum Press.

- $\quad$ Lynch, K. (1960). The image of the city. Cambridge, MA: MIT Press. 
- Marcus CC, Francis C (1990). People Places, Design Guidelines for Urban Open Space, Edited by; Clare Cooper Marcus and Francis, Van Nostrand Reinhold, New York.

- $\quad$ Kent F, Madden K (1998). Urban Parks Online. Creating Great Urban Parks. Urban Parks Institute: Great Parks/Great Cities, Seattle, Wa.

- Nugent, Pam M.S., "FAMILIARITY," in PsychologyDictionary.org, May 11, 2013, https://psychologydictionary.org/familiarity/ (accessed December 26, 2017).

- $\quad$ Shamsuddin, S. \& Ujang, N. (2008). Making places: The Role of Attachment in Creating the Sense of Place for Traditional Streets in Malaysia. Habitat International, 32(3), 399-409.

- Mazumdar, Sh., Mazumdar, S. (2004). Religion and place attachment: A study of sacred places, Journal of Environmental Psychology, 24, 385-397.

- 'Amman municipality building seven new public parks', Suzanna Goussous - Feb 25,2016 - Last updated at Feb 25,2016.

- $\quad$ "Al Hussein Public Parks". Archived from the original on 28 August 2008. Retrieved 2008-08-23.

- Project for Public Spaces (PPS) https://www.pps.org/ Retrieved. https://www.pps.org/article/placemaking-feature-front-and-center-in-nola 